\title{
MANAJEMEN DAN NILAI EKONOMI PENDIDIKAN DASAR DALAM MENINGKATKAN MUTU PENDIDIKAN
}

\author{
Sri Winarsih \\ (Dosen Pasca Sarjana IAINU Kebumen)
}

\begin{abstract}
Management is the all process for carrying out a job through someone else done by two or more people to achieve a state goal which has been determined. In other word, management is a means of managing the organization. Improving the quality of education need to continuous quality improvement which is a formula or approach should be one of the paradigms of school based management. Improvement of quality approach countinuely is expected to overcome the problem of education quality's which is not only uses conventional approaches, but in need of an approach in order to optimize resources and fund. It is intended to achieve state objectives effectively, efficiently, creatively and innovatively. The directions approach to improving the quality of the school led to recognize and implement the total quality management. It is an integrated quality management undertaken by all levels of management and the institutional part of the system with the goal of providing outstanding service to customer. Then every school must optimize the management to improve the quality and economic value. Economic value of primary education can provide several benefits including, namely: social and economy benefits.
\end{abstract}

Keywords: Management, Economic V alue of Primary Education Quality.

\section{A. Pendahuluan}

Masalah pendidikan sebenarnya tidak dapat dilepaskan dari masalah ekonomi. Baik secara langsung maupun tidak langsung, kontribusi pendidikan terhadap ekonomi dan pembangunan harus diakui. Dengan demikian, tidak selamanya pendidikan dianggap sebagai konsumsi atau pembiayaan. Sudah saatnya, pendidikan harus dipandang sebagai investasi, yang secara jangka panjang kontribusinya dapat dirasakan.

Untuk menjawab hal tersebut di atas, kita tidak dapat melepaskan diri dari masalah pembangunan. Konsep pembangunan dalam bidang sosial ekonomi sangat beragam tergantung konteks pengggunaanya. Ahli-ahli ekonomi mengembangkan teori pembangunan yang didasari kepada kapasitas produksi tenaga manusia di dalam proses pembangunan, yang kemudian dikenal dengan istilah Invesment in Human Capital. Teori ini didasari 
pertimbangan bahwa cara yang paling efisien dalam melakukan pembangunan nasional suatu negara terletak pada peningkatan kemampuan masyarakatnya. Selain itu dihipotesiskan pula bahwa faktor utama yang mendukung pembangunan adalah pendidikan masyarakat.

Pendidikan masyarakat diawali dari pendidikan dasar. Pendidikan dasar adalah jenjang pendidikan formal yang mendasari pendidikan menengah dan tinggi,meliputi SD/MI dan SMP/MTS. Jenjang pendidikan ini berperan untuk mengembangkan kemampuan pribadi, sosial, lanjut studi, dan persiapan karier. Pendidikan dasar masih memiliki sejumlah masalah berkenaan dengan mutu proses dan hasil pendidikan, jumlah dan sebaran guru, kinerja dan efektivitas penggunaan waktu belajar, biaya, dan sarana prasarana pendidikan.

Pendidikan dasar bertujuan membangun landasan bagi berkembangannya potensi peserta didik agar menjadi manusia beriman dan bertaqwa kepada Tuhan Yang Maha Esa, berakhlak mulia, sehat, berilmu, cakap,. Kritis, kreatif, inovatif, mandiri, percaya diri, dan menjadi warga Negara yang demokratis dan bertanggung jawab untuk mengikuti pendidikan lebih lanjut sejalan dengan pencapaian tujuan pendidikan nasional (Pasal 12 Ayat 2)

Fungsi dan tujuan pendidikan dasar tersebut sejalan dengan keadaan sosial-budaya serta tingkat perkembangan dan kebutuhan masyarakat Indonesia. Pada dasarnya di Indonesia tujuan pendidikannya lebih mengedepankan keimanan, ketakwaan dan akhlak mulia. Jenjang pendidikan dasar berada pada usia sekitar 6 sampai dengan 15 tahun, anak pada usia ini mengalami perkembangan fisik dan motorik yang sangat cepat.

\section{B. Pengertian Manajemen.}

Sebelum mengetahui bagaimana pengaruh manajemen terhadap mutu dan organisasi, alangkah baiknya kita telusuri dulu makna dari manajemen itu sendiri.

Pada saat ini manajemen sudah banyak dikenal di kalangan masyarakat secara luas. Setiap organisasi baik yang mencari keuntungan maupun lembaga sosial hampir semuanya menyadari pentingnya manajemen.

Kata manajemen menurut asal katanya (etimologis) berasal dari bahasa latin, manusagere. Manus berarti tangan,sedangkan agere berarti melakukan.Digabungkan menjadi kata kerja Managere yang artinya menangani.Managere diterjemahkan ke dalam bahasa Inggris dalam bentuk kata kerja to manage,dengan kata benda Management, manager untuk orang yang melakukan kegiatan manajemen. 
Menurut Nur Aedi (2012:26) Manajemen adalah keseluruhan proses untuk melaksanakan suatu pekerjaan melalui orang lain yang dilakukan oleh dua orang atau lebih untuk mencapai suatu tujuan bersama yang telah ditentukan atau diputuskan sebelumnya. Dengan demikian dapat pula dikatakan bahwa manajemen merupakan alat pelaksana Organisasi. ${ }^{1}$ Sedangkan ilmu manajemen dapat diberikan suatu pengertian yang cukup sederhana yaitu suatu ilmu yang mempelajari bagaimana cara mencapai suatu tujuan dengan efektif serta efisien dengan menggunakan bantuan/melalui orang lain". ${ }^{2}$ Yang dimaksud menggunakan bantuan/melalui orang lain adalah dapat berupa bantuan orang lain dalam wujud fikiran, tenaga serta dapat pula intuisinya.

\section{Definisi Mutu.}

Pengertian mutu sendiri menurut Deming ialah kesesuaian dengan kebutuhan. Sedangkan menurut Juran, mutu ialah kecocokan dengan kebutuhan. Sallis (2003) mengemukakan bahwa mutu adalah konsep yang absolut dan relatif. Mutu yang absolut adalah mutu yang mempunyai idealisme tinggi dan berstandar tinggi yang harus dipenuhi, dengan sifat produk bergengsi yang tinggi. Sedangkan mutu relatif adalah sebuah alat yang sudah ditetapkan dan harus memenuhi standar yang telah dibuat.

Telah diketahui bahwa Lembaga Pendidikan adalah sebuah kegiatan yang melayani konsumen berupa murid, siswa mahasiswa dan masyarakat umumyang dikenal sebagai stakeholder. ${ }^{3}$ Mereka membutuhkan layanan dari lembaga pendidikan. Sedangkan guru adalah orang pertama yang ditampilkan mewakili lembaga tersebut dalam hal mutu pendidikan. Di dalam meningkatkan mutu pendidikan perlu adanya perbaikan mutu berkelanjutan (Continuos quality improvement), merupakan suatu formula atau pendekatan yang seharusnya menjadi salah satu paradigma Manajemen Berbasis Sekolah (MBS).

Melalui pendekatan perbaikan mutu berkelanjutan di harapkan dapat mengatasi masalah rendahnya mutu pendidikan yang tidak hanya mengandalkan pendekatan yang bersifat konvensional,melainkan di butuhkan suatu pendekatan dalam rangka optimalisasi sumber daya dan

${ }^{1}$ Nur Aedi, Dasar-dasar manajemen pendidikan, (Bandung:CV.Pustaka Cendekia Utama, 2012), hlm. 26

2Djati Julitriarsa, John Suprihanto, Cet. Ketiga, 1998, “Manajemen Umum”, (Yogyakarta: BPFE), hlm. 1

${ }^{3}$ Buchari Alma \& Ratih Hurriyati, Manajemen Corporate \& Strategi Pemasaran Jasa Pendidikan (Fokus pada mutu dan layanan Pendidikan).(Bandung:CV Alfabeta,2008).hlm.30 
sumber dana.Hal itu dimaksudkan untuk mencapai sasaran secara efektif,efisien,kreatif dan inovatif yang berorientasi kepada peningkatan mutu (kualitas).Arah pendekatan perbaikan mutu menggiring sekolah untuk mengenal dan mengimplementasikan Total Quality Management (TQM). TQM adalah manajemen mutu terpadu yang dilakukan oleh setiap tingkatan manajemen dan bagian dalam sistem kelembagaan/organisasi dengan tujuan memberikan pelayanan yang memuaskan terhadap pelanggan/pemakai (customer). ${ }^{4}$

Konsep dan pendekatan ini menawarkan sejumlah rumusan yang dapat dilakukan dalam kegiatan manajemen yang berorientasi kepada peningkatan mutu secara total.Berbagai aspek yang terkait dengan mutu yang dilakukan dalam kegiatan pengelolaan sekolah senantiasa dihadapkan kepada persoalan sejauhmana mutu dapat dicapai. Selain itu dalam meningkatkan mutu sekolah, seorang pemimpin harus menguasai manajemen pendidikan untuk meningkatkan mutu pendidikan di sekolah dan nilai ekonomi pendidikan dasar.

Menurut Engkoswara (2001:2) manajemen pendidikan adalah suatu ilmu yang mempelajari bagaimana menata sumber daya untuk mencapai tujuan yang telah ditetapkan secara produktif dan bagaimana tujuan yang disepakati bersama. Karena itu, agar proses penyelenggaraan organisasi dapat terlaksana secara efektif, maka penataan berbagai sumberdaya pendidikan dan penciptaan suasana yang kondusif harus dilakukan.

Untuk itu, pemimpin pendidikan harus menguasai wilayah kerja manajemen pendidikan

\begin{tabular}{|l|l|l|l|}
\hline \multicolumn{4}{|c|}{ perorangan } \\
\hline \multicolumn{1}{|c|}{ Garapan } & SDM & SB & SFD \\
Fungsi & $\mathrm{X}$ & & \\
\hline Perencanaan & $\mathrm{X}$ & & \\
\hline Pelaksanaan & $\mathrm{X}$ & \\
\hline Pengawasan & Kelembagaan \\
\hline
\end{tabular}

Gambar

Ruang Lingkup Manajemen Pendidikan

(Engkoswara, 2001: 2)

${ }^{4}$ Nanang Fattah, konsep Manajemen Berbasis sekolah (MBS) dan Dewan Sekolah, (Bandung:Pustaka Bani quraisy, 2003), hlm.107. 


\section{Nilai Ekonomi dari Pendidikan Dasar}

Ilmu Ekonomi menanyakan barang apa (What) yang akan diproduksi, bagaimana (bow) barang dan jasa itu diproduksi,dan untuk siapa (for whom) barang dan jasa itu diproduks. ${ }^{5}$ Fangerlind, Ingemar dan Saha (1983) mengemukakan bahwa teori human capital pertama sekali diperkenalkan oleh Theodore Shult (1960) dalam tulisannya yang bertema Invesment in buman capital, ia menyatakan bahwa pendidikan tidak boleh diartikan sebuah "konsumsi" tetapi pendidikan harus diartikan sebagai "investasi" produktif. Investasi pendidikan adalah pembiayaan modal pengadaan sarana dan prasarana pendidikan,dan biaya pegelolaan yaitu pembiayaan guru,pegawai, PBM dan KBM,administrasi dan tata usaha, dan pemeliharaan termasuk perawatan inventaris dan sarana lainnya.

Teori buman capital mengasumsikan bahwa pendidikan formal merupakan instrumen terpenting untuk menghasilkan masyarakat yang memiliki produktifitas yang tinggi. Menurut teori ini pertumbuhan dan pembangunan memiliki 2 syarat, yaitu; 1 Adanya pemanfaatan teknologi tinggi secara efisien.

2. Adannya sumber daya manusia yang dapat memanfaatkan teknologi yang ada. Sumber daya manusia seperti itu dihasilkan melalui proses pendidikan. Hal inilah yang menyebabkan teori buman capital percaya bahwa investasi dalam pendidikan sebagai investasi dalam meningkatkan produktivitas masyarakat.

Asumsi dasar yang melandasi keharusan adanya hubungan pendidikan dengan penyiapan tenaga kerja adalah bahwa pendidikan diselenggarakan untuk meningkatkan keterampilan dan pengatahuan untuk bekerja. Dengan kata lain, pendidikan menyiapkan tenaga-tenaga yang siap bekerja. Namun demikian pada kenyataannya tingat pengangguran di hampir seluruh negara bertambah sekitar $2 \%$ setiap tahunnya (World Bank:1980).

Terjadinya pengangguran bukan disebabkan tidak berhasilnya proses pendidikan, namun pendidikan tidak selalu harus menghasilkan lulusan dengan jenis pekerjaan tertentu. Sekolah memang dapat menghasilkan tenaga kerja dengan keterampilan tertentu, tetapi sekolah bukan satusatunya tempat dimana keterampilan itu dapat dicapai.

Menurut Syaiful Sagala (2009:6) Pendidikan adalah proses pengubahan sikap dan tata laku seseorang atau kelompok orang dalam usaha mendewasakan manusia melalui upaya pengajaran dan pelatihan

${ }^{5}$ Nanang Fattah, Ekonomi dan Pembiayaan Pendidikan (Bandung:PT Remaja Rosdakarya, 2004), hlm.11. 
sebagai layanan belajar. ${ }^{6}$ Jadi Ekonomi Pendidikan adalah studi tentang bagaimana orang-orang dan masyarakat, memilih dengan atau tanpa memakai uang, memilih untuk memanfaatkan sumber-sumber daya produksi yang langka untuk menghasilkan berbagai tipe pelatihan, pengembangan pengetahuan, keterampilan, pikiran, karakter dan seterusnya terutama melalui persekolahan formal selama rentang waktu tertentu, dan untuk mendistribusikan mereka, kini dan pada masa depan, kepada berbagai orang dan kelompok dalam masyarakat. ${ }^{7}$

Terdapat berbagai macam faktor untuk mengukur bagaimana pertumbuhan ekonomi diukur dengan baik. Diantara ukuranukuran tersebut, diantaranya:

1. Pendapatan per-kapita

2. Perubahan peta ketenagakerjaan dari pertanian ke industry

3. Konsumsi energi atau pemakaian barang berteknologi tinggi seperti mobil, telepon, televisi.

Dengan demikian kriteria untuk menilai keberhasilan pembangunan:

1. Peningkatan dalam efisiensi sistem produksi masyarakat yang diukur dengan GDP dan GNP.

2. Kepuasaan pemenuhan kebutuhan dasar masyarakat

3. Pencapaian tujuan-tujuan oleh berbagai kelompok dalam masyarakat, yang dikaitkan dengan penggunakan sumber daya yang terbatas.

Pola keterkaitan antara pendidikan dan pembangunan berbeda sesuai dengan karakteristik khas setiap negara. Secara ringkas tampak berikut ini:

a. Negara Kapitalis vs Negara Sosialis.

Ekonomi di negara kapitalis mengasumsikan bahwa model produksinya bebas dari intervensi pemerintah dan mensyaratkan adanya kompetisi terbuka di dalam pemasaran. Hubungan antara pendidikan dan pertumbuhan ekonomi sangat erat dan pendidikan merupakan suatu hal yang diperlukan. Ekonomi di negara sosialis, memiliki konteks yang berbeda dalam mengitepretasikan pertumbuhan ekonomi dan pembangunan. Pemerintah memiliki peranan di dalam mengontrol jalannya proses produksi dan pemasaran. Kaitan antara pendidikan dengan pertumbuhan ekonomi dan pembangunan seolah tidak terlihat karena pembangunan sangat diatur oleh negara, bukan ditentukan oleh masing-masing warga negara.

'Syaiful Sagala, Manajemen Strategik dalam Peningkatan Mutu Pendidikan, (Bandung:CV.Alfabeta, 2009), hlm.6

${ }^{7}$ Syaiful Sagala, Manajemen Strategik dalam Peningkatan Mutu Pendidikan, (Bandung: CV.Alfabeta, 2009), hlm.210 
b. Negara Industri vs Non-Industri.

Di Amerika Serikat yang sudah maju, persentase pekerja yang bekerja di sektor industri sebesar $33 \%$ dan di bidang jasa/service sebesar 66 $\%$. Di Meksiko persentase di sektor yang sama adalah $23 \%$ dan $33 \%$. Di negara maju, penduduknya memiliki pendapatan perkapita yang lebih tinggi, pemakaian teknologi yang canggih, konsumsi energi yang lebih besar dibandingkan negara kurang berkembang. Di negara maju memiliki akumulasi modal yang lebih besar, sebagai akibat dari kelebihan pendapatan setelah dikurangi kebutuhan konsumsi, sehingga jumlah tabungan semakin lebih besar dan pada akhirnya akan diinvestasikan lagi pada sistem ekonomi yang telah berjalan. Hubungan antara pendidikan dan pembangunan di negara maju sangat jelas dilihat dari adanya perubahan karakteristik individu yang berkaitan dengan tingkat pertumbuhan ekonomi. Di negara nonindustri, perekonomiannya sangat tergantung kepada sektor pertanian sehingga persentase tenaga kerjanya lebih banyak yang bekerja di sektor non-industri.

Jelas bagaimana pentingnya analisis kontribusi pendidikan dalam pembangunan. Salah satu alasan banyaknya kontroversi tentang kaitan antara pembangunan dan pendidikan disebabkan karena sedikit sekali kebijakan pendidikan yang dimonitor benar-benar dan juga dievaluasi hasilnya. Analisis terhadap pendidikan biasanya bersifat ex-post fakto, artinya data diperoleh dari kejadian-kejadian yang telah lampau. Sebenarnya konsep bagaimana pendidikan itu harus dievaluasi harus dikembangkan sejak tujuannya ditetapkan. dengan memperhatikan kerangka berpikirnya dan metodologinya. Metode yang sering dipakai dalam penelitian evaluasi adalahl linear regresion and the educational production.

Berdasarkan hal tersebut di atas, maka untuk membicarakan lebih lanjut kontribusi pendidikan terhadap pembangunan harus ditemukan kriteria-kriteria atau ukuran-ukuran pertumbuhan atau hasil pembangunan. Dari uraian di atas, maka dapatlah dirumuskan ukuran-ukuran sebagai berikut.:
a) Teknologi tinggi dan sumberdaya yang mengoperasikannya
b) Pendapatan per-kapita
c) Perubahan peta ketenagakerjaan dari pertanian ke industry
d) Konsumsi energi atau pemakaian barang berteknologi tinggi
e) Peningkatan dalam efisiensi sistem produksi masyarakat yang diukur dengan GDP dan GNP
f) Kepuasan pemenuhan kebutuhan dasar masyarakat 
g) Pencapaian tujuan-tujuan oleh berbagai kelompok dalam masyarakat, yang dikaitkan dengan penggunakan sumber daya yang terbatas.

Berdasarkan ukuran tersebut di atas, maka untuk mengetahui keterkaitan antara pendidikan dan pembangunan diperlukan data sebagai berikut.

Pendidikan, yang meliputi partisipasi pendidikan untuk setiap jenis dan jenjang pendidikan. Pendapatan nasional, baik dalam bentuk Pendapatan Nasional Bruto, Pendapatan Domestik Bruto, maupun Pendapatan Perkapita Perubahan peta ketenagakerjaan, dengan rentangan pertanian-jasaindustri Konsumsi energy Konsep Investasi dalam Pendidikan.

Investasi berarti penanaman modal atau uang. Modal atau uang yang ditanamkan bertujuan untuk mendapatkan keuntungan, baik berupa uang atau modal maupun dalam bentuk barang atau jasa. Kenneth J. Arrow (1962) mengemuikakan bahwa istilah investasi atau investment merupakan alokasi current resources yang mempunyai alternatif produktif yang berguna untuk pelaksanaan kegiatan yang dapat menambah keuntungan yang diperoleh di masa yang akan datang. Biaya atau cost suatu investasi merupakan keuntungan yang diperoleh dibagi dengan penggunaan sumber daya dalam berbagai kegiatan lain. Dengan demikian jelas bahwa investasi merupakan penanaman modal atau uang yang sengaja dilakukan untuk mendatangkan keuntungan melalui produk yang dihasilkan. Sementara itu pendidikan merupakan usaha manusia untuk membangun manusia itu sendiri dengan segala masalah dan spektrumnya yang terlepas dari dimensi waktu dan ruang. Hal ini berarti bahwa inti pendidikan itu adalah pembelajaran seumur hidup (life long learning), sementara bentuk pendidikan formal, pendidikan non formal (luar sekolah) dan sebagainya hanya merupakan modus operandi dari proses pendidikan. Pendidikan di sini dimaksud untuk meningkatkan martabat manusia agar mempunyai ketermapilan dan kemampuan sehinggan produktivitasnya meningkat. Oleh sebab itu maka hasil pendidikan akan menjadi sumber daya manusia yang sangat berguna dalam pembangunan suatu negara.

Investasi dalam pendidikan merupakan penanaman modal dengan cara mengalokasikan biaya untuk penyelenggaraan pendidikan serta mengambil keuntungan dari sumber daya manusia yang dihasilkan melalui pendidikan itu. Dalam konteks ini pendidikan ini diapandang sebagai industri pembalajaran manusia, artinya melalaui pendidikan dihasilkan manusia-manusia yang mempunyai kemampuan dan keterampilan yang sangat diperlukan bagi perekonomian suatu negara untuk meningkatkan 
pendapatan individu dan pendapatan nasional. Dengan demikian maka investasi dalam pendidikan mempunyai jangka waktu yang panjang untuk dapat mengetahui hasilnya dan hasilnya itupun tidak dalam bentuk keuntungan lansung, melainkan keuntungan bagi pribagi yang menerima pendidikan dan bagi negara.

Sebagai fungsi investasi, pendidikan memberikan sumbangan yang berarti dalam kenaikan tingkat kehidupan, kualitas manusia dan pendapatan nasional, terutama dalam hal-hal berikut:

a) Proses belajar mengajar menjamin masyarakat yang terbuka (yaitu masyarakat yang senantiasa beresedia untuk mempertimbangkan gagasan-gagasan dan harapan-harapan baru serta menerima sikap dan proses baru tanpa harus mengorbankan dirinya).

b) Sistem pendidikan menyiapkan landasan yang tepat bagai pembangunan dan hasil-hasil rises (jaminan melekat untuk pertumbuhan masyarakat modern yang berkesinambungan). Investasi pendidikan dapat mempertahankan keutuhan dan secara konstan menambah persediaan pengetahuan dan memungkinkan riset dan penemuan metode serta teknik baru yang berkelanjutan.

c) Apabila dalam setiap sektor ekonomi kita dapatkan segala faktor yang dibutuhkan masyarakat kecuali tenaga kerja yang terampil, maka investasi dalam sektor pendidikan akan menaikan pendapatan perkapita dalam sektor tersebut, kecuali bila struktur sosial yang hidup dalam masyarakat tersebut tidak menguntungkan.

d) Sistem pendidikan menciptakan dan mempertahankan penawaran ketermapilan manusia di pasar pemburuhan yang luwes dan mampu mengakomodasi dan beradaptasi dalam hubungannya dengan perubahan kebutuhan akan tenaga kerja dan masyarakat teknologi modern yang sedang berubah (Komaruddin, 1991: 14).

Investasi dalam pendidikan memusatkan perhatian pada manusia sebagai sumber daya yang akan menjadi modal (buman capital) bagai capital (Gary S. Backer, 1962) berkenaan dengan kegiatan-kegiatan yang mempengaruhi real income masa yang akan datang melalui penempatan sumber daya dalam bentuk manusia. Human capital di sini merujuk pada tenaga kerja sebagai suatu faktor produksi yang menghubungkan aspek nonekonomi pendidikan terhadap aspek ekonomi lainnya yang mempunya dua ciri esensial, yaitu:

a) Kualitas tenaga kerja sebagai suatu input produktif tidak dapat dibagi dan digunakan secara terpisah. 
b) Kemampuan tenaga kerja tersebut tidak dapat dipindahkan kepada orang lain.

\section{E. Implementasi Kebijakan Anggaran Pendidikan Dasar}

Kebijakan desentralisasi pendidikan dalam kerangka otonomi daerah menuntut tanggung jawab pemerintah kabupaten/kota dalam mengatasi permasalahan pendidikan. Hambatan di bidang pendidikan dari dulu hinggga era otonomi belum bergeser. Persoalan pendidikan di daerah masih sekitar sarana dan prasarana yang tidak lengkap, jumlah dan mutu pengajar yang kurang dengan ketersebaran yang tidak merata. Akibatnya, kegiatan belajar-mengajar yang mengarah pada upaya perbaikan hasil belajar sulit terwujud. Banyak pihak menilai pelayanan pendidikan di era otonomi daerah tidak menunjukkan perubahan berarti, bahkan cenderung memburuk. Permasalahan ini antara lain disebabkan pengelolaan APBD yang belum sepenuhnya mendukung pelaksanaan desentralisasi pendidikan, sehingga menjadi kendala pencapaian berbagai sasaran programyang telah ditetapkan, khususnya dalam meningkatkan pelayanan pendidikan dasar.

Salah satu kebijakan penting dalam meningkatkan pelayanan pendidikan di Jawa Barat adalah penuntasan wajar diknas 9 tahun pada tahun 2008. Dengan berangkat pada angka partisipasi murni (APM) SD/MI dan SMP/MTS tahun 2004 96,12\% dan 60,27\% dan tahun 2005 APM SD/MI 97059\% dan APM SMT/MTS 86,2\%. Penuntasan wajar dikdas 9 tahun sampai dengan 2004-2005 terlihat dari pencapaian pergerakan angka partisipasi yang lambat, terutama di jenjang SMP/MTs, realitas pencapaian APM SMP/MTs baru mencapai 60,27\%. Padahal jika mengikuti standar Depdiknas, kategorituntas pertama jika APM berkisar antara 80\%-85\%, tuntas madya APM 86\%-90\%, dan tuntas paripurna antara 96\%-100\% (Dinas Pendidikan Jabar,2005).

Data yang berhasil dihimpun dari berbagai sumber menunjukkan bahwa pada tahun 2005, jumlah anak usia sekolah yang tidak menikmati bangku sekolah sebagai akibat kemiskinan sebanyak $265.000(20,72 \%)$ dari seluruh anak usia 7-15 tahun. Anak yang putus sekolah sebanyak 1.278.946 orang $(34,8 \%)$ dari seluruh anak yng berjumlah 6.745 .272 orang. Jumlah buta huruf di Jawa Barat mencapai 216.758 orang $(77,2 \%)$. Anak usia 7-15 tahun yang sudah memiliki kesempatan menikmati bangku sekolah pun tidak terjamin bisa mendapatkan kualitas pelayanan yang memadai karena lebih dari 50\% sekolah dasar dan menengah negeri di Jawa Barat masih berkutat pada permasalahan kekurangan guru dan keterbatasan sarana danprasarana penunjang kegiatan belajar-mengajar. 
Jawa Barat pada tahun 2005, masih kekurangan guru 81.000 orang diantaranya 48.000 guru sekolah dasar (SD) atau 59\%, 24.000 guru SLTP atau 30\%. Bangunan sekolah yang rusak di Jawa Barat 47.000 buah, di antaranya 43.000 bangunan sekolah dasar (SD) dan 3.000 bangunan SLTP (Pikiran rakyat, 2005). Masih belum optimalnya pelayanan pendidikan dasar di Jawa Barat tersebut diantaranya tidak terlepas dari besaran alokasi anggaran pendidikan, baik dari APBD provinsi dan APBD kabupaten/kota.

Realitasnya pemerintah daerah tidak konsisten dengan ketentuan pemenuhan anggaran pendidikan 20\% dari APBD. Contohnya, APBD Provinsi Jawa Barat pada tahun yang 2005 sebesar Rp.4.131.349.788.522,15, adapun anggaran Dinas Pendidikan Jawa Barat sebesar Rp.359.598.068,20 berkisar 8,7\%. Pada tahun 2006 anggaran sektor pendidikan baru mencapai $7,8 \%$ dari total APBD. Demikian pula APBD kabupaten/kota masih jauh dari harapan.

Beragam persoalan krusial dalam pembangunan pendidikan di Jawa Barat, salah satunya bermuara pada lemahnya implementasi kebijakan anggaran dalm bentuk peaturan daerah tentang APBD, sebagai produk bersama antara eksekutif dan legislatif. Perhatian lembaga-lembaga tersebut belum sepenuhnya berpihak pada kepentingan pelayanan pendidikan masyarakat. Faktanya meskipun UU mengamanatkan bahwa anggaran pendapatan harus menyentuh angka $20 \%$, namun dalam implementasinya masih jauh dari harapan.

Berdasarkan penelitian, kebijakan anggaran yang digulirkan pemerintah daerah dalam upaya menuntaskan wajar dikdas 9 tahun belum optimal dan memberikan kepuasan pada masyarakat selaku stakeholders penerima layanan. Mencermati besaran alokasi anggaran pendidikan baik APBD kabupaten/kota hingga tahun 2005 dapat dikemukakan beberapa hal sebagai berikut:

a) Pertama, alokasi anggaran pendidikan masih belum memenuhi amanat konstitusi UUD 1945 dan UU Sisdiknas 20/2003 minimal $20 \%$ dari volume APBN dan APBD.

b) Kedua, dilihat dari proporsi anggaran, belum memadainya anggaran sektor pendidikan menjadi salah satu kendala akselerasi pencapaian wajar 9 tahun.

c) Ketiga, dilihat dari strukur anggaran, dalam implementasinya, khususnya anggaran program pendidikan dasar masih terdapat anggaran pegawai yang memengaruhi besaran anggaran program sehingga mengurangi pembiayaan langsung (direct cost) pada satuan 
pendidikan (sekolah). Oleh karena itu, alokasi anggaran untuk program pendidikan menjadi berkurang.

d) Keempat, dalam konteks pelayanan, dilihat dari struktur, format anggaran, program dan alokasi anggaran, dapat dikatakan bahwa kebijakan anggaran pemerintah daerah kabupaten/kota di Jawa Barat belum mencerminkan keberpihakan pemerintah daerah terhadap kepentingan publik, dalam hal ini pelayanan pendidikan.

Belum optimalnya kebijakan anggaran dalam meningkatkan kualitas pelayanan pendidikan dasar disebabkan enam faktor yang menentukan implementasi kebijakan publik. Masing-masing faktor tersebut memiliki kelemahan (belum terimplementasi semestinya), padahal dari hasil penelitian faktor tersebut memiliki kelemahan (belum terimplementasi semestinya), padahal dari hasil penelitian faktor tersebut menunjukkan pengaruh yang signifikan yakni, kondisi sosial-ekonomi dan politik (17,4\%), standar dan tujuan $(15,4 \%)$, sumber daya $(12,6 \%)$, sikap pelaksana $(11,3 \%)$, struktur birokrasi (10,9\%), dan komunikasi antar organisasi (6,6\%).

Berpijak pada hasil penelitian, faktor penting dalam upaya memajukan pendidikan di Jawa Barat terletak pada faktor kondisi sosial, ekonomi dan politik. Situasi sosial yang kondusif akan memberikan peluang kepada pemerintah untuk memperhatikan sektor pendidikan lebih optimal. Sebaliknya, jika kondisi sosial bergejolak akan memalingkan perhatian pemerintah dari sektor pendidikan dan hanya memfokuskan kepada perbaikan kondisi sosial.

Kondisi sosial dan ekonomi pada dasarnya lebih banyak ditentukan oleh faktor politik. Apabila kecenderungan para elite politik menjadikan pendidikan sebagai prioritas utama, maka masalah-masalah yang melilit sektor pendidikan seperti alokasi anggaran yang memadai tidak akan menjadi masalah. Kuncinya adalah komitmen dan kemauan politik dari para elite penentu kebijakan.

Terkait dengan faktor standar dan tujuan pada implementasi kebijakan anggaran, berbagai program penuntasan wajar dikdas 9 tahun dibuat seideal mungkin oleh semua pemerintah daerah. Namun, ketika kebijakan diimplementasikan terjadi ketidaksesuaian. Dalam arti, pencapaian sasaran program tidak didukung dengan alokasi anggaran yang mencukupi, sehingga menjadi tidak efektif. Padahal setiap program / kegiatan berikut alokasi anggarannya harus dibuat berdasarkan tupoksi, tingkat prioritas program, tujuan, sasaran, yang disertai dengan indikator penilaian kinerja yang jelas dan terukur. Dengan sistem itu, seharusnya setiap biaya satuan 
jenis pelayanan dapat diukur, sehingga tercapai tingkat efektivitas dan efisiensi dari setiap jenis program pelayanan.

Penelitian menemukan pula bahwa pemerintah kabupaten/kota di Jawa Barat belum memiliki standar analisis belanja (SAB). Hal ini pula yang menyebabkan setiap unit kerja memiliki perbedaan perkiraan biaya pendidikan dasar yang harus dikeluarkan. Bahkan bukan hal yang tidak mungkin akan terjadi kecurigaan-kecurigaan di antara stakeholders pendidikan dasar. Dalam penyusunan anggaran sektor pendidikan diperlukan standar pelayanan minimal (SPM). SAB dan standar biaya pendidikan yang memperhitungkan unit cost setiap jenjang pendidikan.

Ketidakcukupan anggaran dalam membiayai program sangat kentara pada faktor sumber daya. Semua sumber daya (guru, gedung sekolah, peralatan, dan fasilitas penunjang lainnya) yang diperlukan dalam implementasi kebijakan pendidikan dasar, khususnya program penuntasan wajar dikdas 9 tahun dan peningkatan kualitas pendidikan dasar banyak yang belum terpenuhi karena keterbatasan anggaran. Hal itu terbukti, misalnya, ada pengadaan sarana dan prasarana pendidikan dasar, kuantitas dan kualitas guru baik di tingkat SD maupun SLTP, terutama didaerah pedalaman masih banyak SD dan SMP/MTs yang kondisi bangunannya sangat memprihatinkan, bahkan tidak sedikit yang sudah ambruk.

\section{F. Investasi di Bidang Pendidikan Dasar}

Investasi di bidang pendidikan tidak saja berfaedah bagi perorangan, tetapi juga bagi komunitas bisnis dan masyarakat umum. Pencapaian pendidikan pada semua level niscaya akan meningkatkan pendapatan dan produktivitas masyarakat. Pendidikan merupakan jalan menuju kemajuan dan pencapaian kesejahteraan sosial dan ekonomi. Sedangkan kegagalan membangun pendidikan akan melahirkan berbagai problem krusial: pengangguran, kriminalitas, penyalahgunaan narkoba, dan welfare dependency yang menjadi beban sosial politik bagi pemerintah. Memasuki abad ke-21, paradigma pembangunan yang merujuk knowledge-based economy tampak kian dominan. Paradigma ini menegaskan tiga hal yaitu:

a) Pertama, kemajuan ekonomi dalam banyak hal bertumpu pada basis dukungan ilmu pengetahuan dan teknologi.

b) Kedua, hubungan kausalitas antara pendidikan dan kemajuan ekonomi menjadi kian kuat dan solid.

c) Ketiga, pendidikan menjadi penggerak utama dinamika perkembangan ekonomi, yang mendorong proses transformasi 
struktural berjangka panjang. Sebagai ilustrasi, Jepang adalah negara Asia pertama yang menjadi pelopor pembangunan perekonomian berbasis ilmu pengetahuan. Setelah Jepang, menyusul negara-negara Asia Timur lain seperti Singapura, China, Taiwan, Hongkong, dan Korea Selatan.

\section{G. Kontribusi Pendidikan}

Sebagai contoh kita akan melihat 3 negara. Kontribusi pendidikan terhadap pembangunan ekonomi dengan melihat perbandingan antara Korea mewakili Asia serta Kenya dan Zimbabwe mewakili Afrika. Pilihan tiga negara ini menarik karena semula Korea, yang secara ekonomi tertinggal, ternyata mampu mengungguli dan kemudian meninggalkan kedua negara Afrika itu.

Beberapa indikator ekonomi makro menunjukkan perubahan amat signifikan antara ketiga negara berbeda benua itu. Yang-Ro Yoon, seorang peneliti ekonomi Bank Dunia, dalam Effectiveness Born Out of Necessity: A

Comparison of Korean and East African Education Policies (2003), mengemukakan sejumlah temuan menarik berdasarkan observasi di tiga negara itu. Pada dekade 1960-an GNP per kapita Korea hanya 87 dollar AS, sementara Kenya 90 dollar AS. Memasuki dekade 1970-an GNP per kapita Korea mulai meningkat menjadi 270 dollar AS, namun masih lebih rendah dibanding Zimbabwe yang telah mencapai 330 dollar AS.

Indikator lain seperti gross savings rate (persentase terhadap GDP) juga menunjukkan, Korea lebih rendah dibanding kedua negara Afrika itu. Pada pertengahan 1970-an, gross savings rate masing-masing negara adalah: Korea 8 persen, Kenya 15 persen, dan Zimbabwe 14 persen.

Meski demikian, dalam hal pembangunan pertanian Korea relatif lebih unggul. Sektor pertanian memberi sumbangan terhadap GDP sebesar 37 persen di Korea, 35 persen di Kenya, dan 20 persen di Zimbabwe.

Memasuki dekade 1980-an, pembangunan ekonomi di Korea berlangsung amat intensif dan pesat. Bahkan antara periode 1980 dan 1996 dapat dikatakan sebagai masa keemasan saat negeri gingseng itu mampu melakukan

transformasi ekonomi secara fundamental. Pada tahun-tahun itu pertumbuhan ekonomi Korea melesat jauh meninggalkan Kenya dan Zimbabwe.Pada tahun 1996 GNP per kapita Korea telah mencapai 10,600 dollar AS (meski lalu menurun menjadi 7.980 dollar AS tahun 1998 saat 
terjadi krisis moneter). Sedangkan GNP per kapita Kenya dan Zimbabwe masing-masing 320 dollar AS dan 610 dollar AS.

Perbedaan yang signifikan juga terlihat pada gross savings rate yakni 36 persen di Korea, 12 persen di Kenya, dan 17 persen di Zimbabwe. Pertumbuhan ekonomi Korea yang mengesankan ini terkait keberhasilan dalam menurunkan angka pertumbuhan penduduk selama tiga dekade: dari 2,7 persen tahun 1962 menjadi 0,9 persen pada 1993. Sementara pertumbuhan penduduk di Kenya justru meningkat dari 3,2 persen tahun 1965 menjadi 4,2 persen tahun 1980, meski kemudian menurun menjadi 2,6 persen pada tahun 1995 .

Tidak diragukan lagi, salah satu kunci keberhasilan pembangunan ekonomi di Korea adalah komitmen yang kuat dalam membangun pendidikan. Berbagai studi menunjukkan, basis pendidikan di Korea memang amat kokoh. Pemerintah Korea mengambil langkah-langkah ekspansif antara 1960-an dan 1990-an guna memperluas akses pendidikan bagi segenap warga negara. Program wajib belajar pendidikan dasar (universal basic education) sudah dilaksanakan sejak lama dan berhasil dituntaskan tahun 1965, sementara Indonesia baru mulai tahun 1984. Sedangkan wajib belajar jenjang SLTP berhasil dicapai tahun 1980-an; dan jenjang SLTA juga hampir bersifat universal pada periode yang sama. Yang menakjubkan, pada jenjang pendidikan tinggi juga mengalami ekspansi besar-besaran; lebih dari setengah anak-anak usia sekolah pada level ini telah memasuki perguruan tinggi.

Komitmen Pemerintah Korea terhadap pembangunan pendidikan itu tercermin pada public expenditure. Pada tahun 1959, anggaran untuk pendidikan mencapai 15 persen dari total belanja negara, guna mendukung universal basic education dan terus meningkat secara reguler menjadi 23 persen tahun 1971. Setelah program ini sukses, Pemerintah Korea mulai menurunkan anggaran pendidikan pada kisaran antara 14 sampai 17 persen dari total belanja negara atau sekitar 2,2 sampai 4,4 persen dari GNP. Menyadari bahwa pendidikan dasar merupakan bagian dari public good, tercermin pada social return lebih tinggi dibanding private return, maka Pemerintah Korea mengalokasikan anggaran untuk pendidikan dasar jauh lebih besar dibanding level menengah dan tinggi.

Penting dicatat, selain faktor basis pendidikan yang lebih kuat, kelas menengah ekonomi di Korea juga terbentuk dengan baik dan mapan. Pada dekade antara 1960-an dan 1980-an, kalangan pengusaha Korea telah 
membangun hubungan dagang dan membuka akses pasar ke negara-negara kawasan seperti Jepang, bahkan telah menyeberang ke Amerika dan Eropa.

Korea sukses melakukan inovasi teknologi (otomotif dan elektronik) karena memperoleh transfer teknologi melalui hubungan dagang dengan negara-negara maju tersebut. Bercermin pada pengalaman Korea, Pemerintah Indonesia harus mengambil langkah-langkah strategis dalam upaya membangun pendidikan nasional. Investasi di bidang pendidikan secara nyata berhasil mendorong kemajuan ekonomi dan menciptakan kesejahteraan sosial.

Untuk itu, investasi di bidang pendidikan harus didukung pembiayaan memadai, terutama yang diperuntukkan bagi penuntasan program wajib belajar pendidikan dasar sembilan tahun. Mengikuti agenda Millenium Development Goals (MDGs), tahun 2015 Pemerintah Indonesia harus menjamin bahwa seluruh anak usia sekolah dasar akan memperoleh pendidikan dasar.

Bersamaan dengan itu, akses ke pendidikan menengah dan pendidikan tinggi juga harus diperluas, guna mendukung upaya menciptakan knowledge society yang menjadi basis akselerasi pembangunan ekonomi di masa depan.

\section{H. Kesimpulan}

Manajemen adalah keseluruhan proses untuk melaksanakan suatu pekerjaan melalui orang lain yang dilakukan oleh dua orang atau lebih untuk mencapai suatu tujuan bersama yang telah ditentukan atau diputuskan sebelumnya. Dengan demikian dapat pula dikatakan bahwa manajemen merupakan alat pelaksana Organisasi. TQM adalah manajemen mutu terpadu yang dilakukan oleh setiap tingkatan manajemen dan bagian dalam sistem kelembagaan/organisasi dengan tujuan memberikan pelayanan yang memuaskan terhadap pelanggan/pemakai (customer). Minimnya anggaran pendidikan, baik yang bersumber dari APBD provinsi maupun kabupaten/kota terutama terkait dengan sikap elite politik dalam menentukan kebijakan anggaran. Masih banyak para penentu kebijakan pemerintah, baik pusat, provinsi dan kabupaten/kota yang memiliki anggapan bahwa pendidikan tidak begitu penting sebab hasilnya sulit diukur dan membutuhkan waktu yang lama untuk menghasilkan sesuatu dan tidak berpengaruh langsung pada produksi. Nilai Ekonomi pendidikan dasar dapat memberikan beberapa keuntungan diantaranya: keuntungan sosial, kontribusi kepada ekonomi nasional, dan kontribusi kepada ekonomi masyarakat. 


\section{DAFTAR PUSTAKA}

Ace Suryadi,1999.Pendidikan, Investasi SDM dan Pembangunan.Jakarta: PT Balai Pustaka.

Becker G.S. 1993. Human Capital, A theoritical and Empirical Analysis with Speccial reference to Education. Chicago, University of Chicago Press

Buchari Alma \& Ratih Hurriyati, 2008. Manajemen Corporate \& Strategi Pemasaran Jasa Pendidikan.Bandung: CV alfabeta.

Cohn. Elchanan, 1979. The Economics Of Education, Ballinger Publishing

Engkoswara. 2002. Lembaga Pendidikan sebagai Pusat Pembudayaan. Bandung, Yayasan Amal Keluarga

Engkoswara. 2001. Paradigma Manajemen Pendidikan Menyongsong Ekonomi Daerah. Bandung : yayasan Amal Keluarga.

Dodi Nandika. 2005. Kebijakan Pembangunan Pendidikan 2005-2009. Bandung UPI.

Djati Julitriarsa, John Suprihanto.1998. “Manajemen Umum”, (Yogyakarta: BPFE)

Nanang fattah.2004.Landasan manajemen pendidikan.Bandung: PT Remaja Rosdakarya.

Nanang fattah. 2000. Ekonomi dan Pembiayaan Pendidikan. Bandung: PT Remaja Rosdakarya.

Nanang fattah, 2003. Konsep Manajemen Berbasis Sekolab (MBS) dan Dewan Sekolah. Bandung: Pustaka Bani Quraisy.

Nur Aedi,2012. Dasar-Dasar Manajemen Pendidikan.Bandung: Pustaka Cendekia Utama. 
Jac Fitz-enz, 2000.The ROI of Human Capital, Measuring the Economic V alue of Employee Performance, New York, Amacom

Syaiful Sagala.2008.Administrasi Pendidikan Kontemporer.Bandung: CV Alfabeta

Syaiful Sagala.2009.Manajemen Strategik dalam Peningkatan Mutu Pendidikan.Bandung: CV Alfabeta.

Tim Dosen Jurusan Administrasi pendidikan.2005. Pengelolaan Pendidikan. Bandung: UPI/Universitas Pendidikan Indonesia. 